IFAS Extension

\title{
Florida Crop/Pest Management Profile: Cabbage ${ }^{1}$
}

\author{
Wael M. Elwakil and Mark Mossler²
}

\section{Production Facts}

- As of 2010, Florida ranks third nationally in the production of fresh market cabbage, accounting for approximately $13 \%$ of U.S. cabbage production. The state ranks third in terms of harvested acres, accounting for approximately $15 \%$ of national cabbage acreage. Florida ranks third in terms of cabbage yield and second in terms of crop value. Florida's crop contributes $8 \%$ to the total national value of fresh market cabbage (USDA/NASS 2011).

- In 2010-2011, cabbage was Florida’s tenth ranking vegetable crop in terms of value and ninth in terms of harvested acreage (Florida Department of Agriculture and Consumer Services 2012).

- In 2009-2010, Florida growers planted 10,500 acres of fresh market cabbage and harvested 9,700 acres. Average yield was 30,000 pounds per acre, and total production was 291 million pounds. The value of Florida's cabbage crop in that year was $\$ 0.24$ per pound, with a total value of $\$ 70.13$ million. Total value of Florida's cabbage crop over the past decade has ranged from $\$ 43.4$ million in 2008 to $\$ 60.3$ million in 2009 (USDA/NASS 2011).

- Florida's cabbage production is exclusively for the fresh market. The higher-quality cabbage obtained during the late fall, winter, and early spring months in Florida allows the shipment of fresh cabbage to areas of the United States that cannot produce cabbage during that part of the year (USDA/NASS 2009; Sargent et al. 2007).

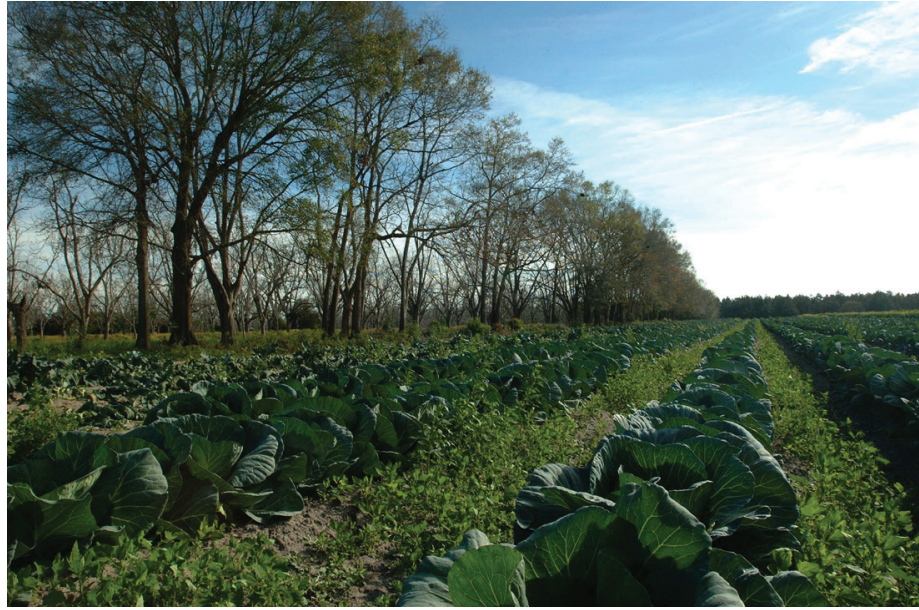

Figure 1. Cabbage crop growing in Alachua County. Credits: IFAS Communications

- Production costs have been estimated for cabbage in the Hastings area (northeast Florida). Total production costs during 2008-2009 were estimated at \$4,057 per acre. Of that total, $\$ 1,572$ represented harvest and marketing costs, while preharvest operating costs totaled $\$ 2,485$. Fungicide expenses totaled $\$ 33$ per acre, while herbicides cost $\$ 34.40$ per acre, and insecticide costs were $\$ 199.33$ per acre. Total cost of pesticide applications, excluding labor and machinery cost, represented $15 \%$ of preharvest operating costs and $6.5 \%$ of total production costs (International Agricultural Trade and Policy Center 2009).

1. This document is CIR1256, one of a series of the Agronomy Department, Florida Cooperative Extension Service, Institute of Food and Agricultural Sciences, University of Florida. Original publication date September 2000. Revised April 2013. Visit the EDIS website at http://edis.ifas.ufl.edu.

2. Wael M. Elwakil, doctor of plant medicine student, and Mark Mossler, pest management information specialist, Pesticide Information Office, Agronomy Department; Florida Cooperative Extension Service, Institute of Food and Agricultural Sciences, University of Florida, Gainesville, FL 32611.

The use of trade names in this publication is solely for the purpose of providing specific information. UF/IFAS does not guarantee or warranty the products named, and references to them in this publication do not signify our approval to the exclusion of other products of suitable composition. 


\section{Production Regions}

The Hastings area in northeast Florida (Flagler and St. Johns Counties) is the principal cabbage-producing region in the state, representing $20 \%$ of the state's cabbage growers and $53.4 \%$ of cabbage acreage. Palm Beach County, in southeast Florida, is another important cabbage-producing area, accounting for $11 \%$ of growers and $12.6 \%$ of acreage. Remaining cabbage production is found throughout the state (USDA/NASS 2009).

\section{Production Practices}

Cabbage is a cool-season crop that grows at a temperature range of $32^{\circ} \mathrm{F}-77^{\circ} \mathrm{F}\left(0^{\circ} \mathrm{C}-25^{\circ} \mathrm{C}\right)$, with an optimum temperature range of $59^{\circ} \mathrm{F}-68^{\circ} \mathrm{F}\left(15^{\circ} \mathrm{C}-20^{\circ} \mathrm{C}\right)$. In Florida, the crop is grown on mineral, sand, and muck soils, although most production is on sandy soils. Cabbage can grow on a range of soil types, but it is sensitive to soil acidity, preferring a $\mathrm{pH}$ of 6.5. The disease club root can become a problem when cabbage is grown in soils with $\mathrm{pH}$ over 7.0 (Leibee 1996).

Nearly all of the cabbage grown in Florida consists of hybrid varieties of green cabbage, with red varieties constituting less than $1 \%$ of production. Examples of green varieties grown in the state include Atlantis, Augusta, Bravo, Cheers, Emblem, Gideon, Gloria, Isalco, Rio Verde, Royal Vantage, and Solid Blue 790. Cardinal and Red Rookie are red varieties planted in Florida (Olson et al. 2012).

Primary planting dates for cabbage in Florida may range from August to March. Planting usually occurs between September and December in northeast Florida, between September and February in central Florida, and between September and January in south Florida (FDACS 2012; Olson et al. 2012).

Seeds are planted at a distance of $24-40$ inches $(61-102 \mathrm{~cm})$ between rows and 9-16 inches $(23-41 \mathrm{~cm})$ between plants, giving a plant population of 29,403 per acre at the closest spacing. When the crop is seeded in double rows in each bed, there are 15-24 inches $(38-61 \mathrm{~cm})$ between rows, and $10-12$ inches $(25-30 \mathrm{~cm})$ within rows centered on beds of $40-60$ inches $(102-152 \mathrm{~cm})$. Seeds are planted at a depth of $0.25-0.5$ inches $(0.6-1.3 \mathrm{~cm})$. Depending on variety and climate conditions, seed to maturity takes between 85 and 110 days, and transplanting to maturity takes between 70 and 90 days (Olson et al. 2012).

Direct-seeding of cabbage on sandy soils tends to lead to poor germination. In addition, broadleaf weed management is more difficult when the crop is direct-seeded. As a result, approximately $90 \%$ of Florida's cabbage crop is transplanted. Many transplants are grown outside in open beds. Bare-root plants are taken from beds in the field, or container-grown plugs are brought in from greenhouses. Florida growers have access to container-grown cabbage transplants throughout the year, and using container-grown rather than bare-root transplants has been on the rise. Most cabbage in Florida is planted using mechanical transplanters (Leibee 1996).

The cabbage crop requires about one inch of water each week, and supplying water in even amounts throughout the season prevents cracking of the heads. Irrigation use during the winter months varies throughout the state. The crop in southern Florida may use 0.10 inches per day $(2,700$ gallons/acre/day), while in north Florida the average may be 0.06 inches per day (1,600 gallons/acre/day). In 1997, $86 \%$ of cabbage-producing farms and $99 \%$ of the state's cabbage acreage were irrigated. Seepage-type irrigation is the most commonly used irrigation on Florida cabbage. Subsurface irrigation is used on sandy soils with a high water table. Drip irrigation is also common, particularly on deeper sands (Olson et al. 2012; USDA/NASS 2012).

Cabbage uses high amounts of nitrogen and potassium. In 2010, 88\% of cabbage acreage in Florida received an average of 2.7 applications of nitrogen annually. An average of 56 pounds of nitrogen per acre has been used at each application (approximately 150 pound per acre annually), with a statewide annual total of 1,390,000 pounds. An average of 46 pounds per acre of phosphate has been applied an average of 1.4 times (about 64 pound per acre annually) to $84 \%$ of the state's cabbage acreage, with total annual state usage of 567,000 pounds. Potash has also been applied 1.6 times per year to $88 \%$ of Florida's cabbage acreage. An average of 113 pounds of potash per acre has been used at each application (about 185 pound per acre annually), with a total annual state usage of $1,708,000$ pounds (USDA/ NASS 2010a).

Cabbage in Florida is usually harvested between October 25 and June 15, with the most active harvest period between January 1 and April 15 (FDACS 2012). Grading is often done in the field. Usually, about three or four of the green wrapper leaves are left on each head at harvest unless they are damaged by worms. The wrapper leaves help to protect the head during harvest and shipment (Sargent et al. 2007).

Cabbage is usually packed into crates or cartons directly in the field without washing. Occasionally it is put into bags and then onto pallets. Cabbage in Florida is shipped under refrigeration, but it is usually not rapidly pre-cooled. 


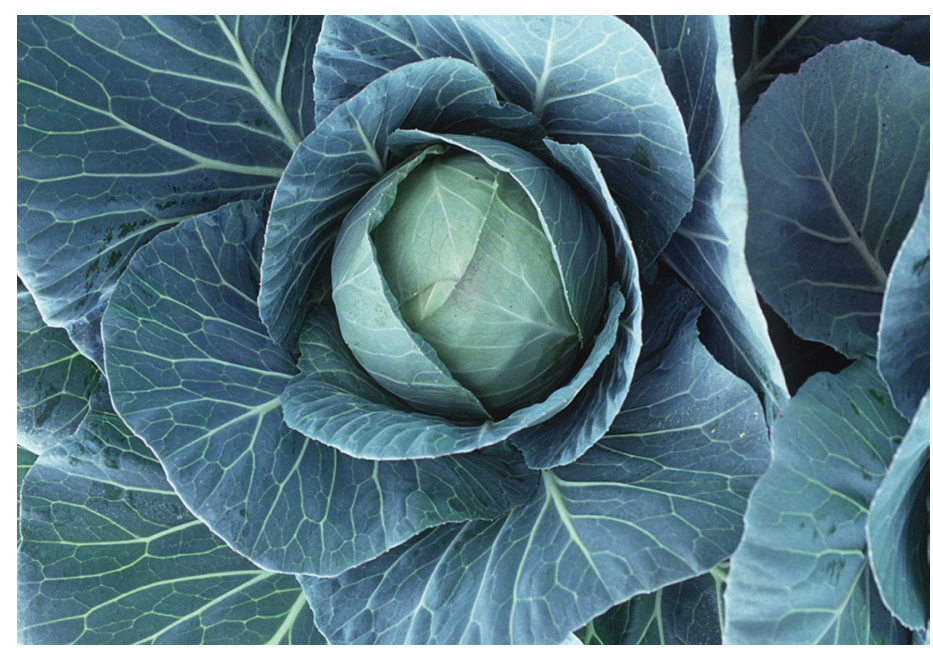

Figure 2. A few leaves are usually left on cabbage to protect the head during shipment.

Credits: IFAS Communications

Some cabbage is forced air-cooled, usually on a leased trailer equipped with an oversized refrigeration system. In this case, the boxed cabbage is put directly from the field into the trailer for 1-2 hours to be cooled and then loaded onto another refrigerated trailer for distribution. However, cabbage prices sometimes drop so low that it becomes uneconomical to cool the crop before shipment (Sargent et al. 2007). Nearly all of Florida's out-of-state cabbage shipments go to markets in the eastern United States.

Since cabbage is easily bruised, care must be taken in handling during harvest and shipment. Pre-cooling cabbage helps to minimize damage, as does harvesting during the cooler part of the day and avoiding rough handling. Exposure to very small quantities of ethylene can also produce damage in cabbage, particularly yellowing and shedding of outer leaves. Cabbage should not be stored with ethylene-producing fruits and vegetables. Fresh cabbage has a maximum storage life of 3-6 weeks when kept at approximately $32^{\circ} \mathrm{F}\left(0^{\circ} \mathrm{C}\right)$ with $90 \%-95 \%$ relative humidity (Sargent et al. 2007).

\section{Worker Activities}

There are no thinning activities for Florida cabbage because $90 \%$ of growers set transplants. Workers either stock the transplanting machine or set transplants by hand. A transplanting crew can set approximately eight acres per day. Large contract growers purchase hybrid seed that assures each cabbage is the same size when picking occurs. Truck farmers generally pick two or three times, without a mechanical harvest. A group of approximately 10 people work with one wagon and hand-harvest the cabbage. This group can cover between four and seven acres per day and generally work bare-handed (Leibee 2004; Stall 2004).

\section{Insect/Mite Management}

\section{Insect/Mite Pests}

Insects are the principal pests found on cabbage in Florida. The greatest insect problem for Florida growers is the diamondback moth (Plutella xylostella). Cabbage looper (Trichoplusia $\mathrm{ni}$ ) is also considered a major pest, but it has been less of a problem over the past decade. Some insect pests have been considered major in the past but are only occasional problems now, including aphids, beet armyworm (Spodoptera exigua), cabbage webworm (Hellula rogatalis), imported cabbageworm (Artogeia rapae), cutworms, and mole crickets. All of the minor pests on Florida cabbage have the potential to become major pests, but they are currently being controlled by treatments for diamondback moth. Silverleaf whitefly (Bemesia argentifolii) and vegetable leafminer (Liriomyza trifolii) are more significant in southern Florida, where silverleaf whitefly is considered a major pest and vegetable leafminer a minor pest (Hayslip et al. 1953; Webb 2010).

Additional insect pests that occasionally cause minor damage to Florida cabbage include southern armyworm (Spodoptera eridania), yellow-striped armyworm (Spodoptera ornithogalli), fall armyworm (Spodoptera frugiperda), blister beetles (Epicauta spp. and Macrobasis unicolor), cabbage budworm (Hellula phidilealis), corn earworm (Helicoverpa zea), cross-striped cabbageworm (Evergestis rimosalis), flea beetles (Phyllotreta spp.), grasshoppers, gulf white butterfly (Ascia monuste), harlequin bug (Murgantia histrionica), horned squash bug (Anasa armigera), onion thrips (Thrips tabaci), saltmarsh caterpillar (Estigmene acrea), southern cabbageworm (Pontia protodice), southern green stinkbug (Nezara viridula), spotted cucumber beetle (Diabrotica undecimpunctata howardi), tarnished plant bug (Lygus lineolaris), vegetable weevil (Listroderes costirostris obliquus), and yellow-margined leaf beetle (Microtheca ochroloma) (Leibee 1996; Webb 2010).

\section{DIAMONDBACK MOTH (PLUTELLA XYLOSTELLA)}

Diamondback moth became the principal pest on Florida cabbage in the 1980s, and it remains one of the most serious problems for the state's cabbage growers, occurring annually (Leibee 1996; Webb 2010). Plants at all stages of growth may be attacked. The moth lays its eggs in groups of 2-3 on the lower surface of leaves. In approximately one day the eggs hatch, and the larvae begin to feed on the leaves. Feeding results in many small holes that grow larger as the larvae increase in size. Often, feeding does not go through the entire leaf, leaving a thin layer of the leaf epidermis. In 
addition to the leaves, diamondback moth larvae can attack the developing cabbage heads, producing shallow tunnels on the tops of heads. The resulting damage deforms the heads and leaves entry points for decay pathogens (Hayslip et al. 1953).

The larval stage can range from 10 days to a month, depending on temperature. Diamondback moth larvae slow their feeding at temperatures below $50^{\circ} \mathrm{F}\left(10^{\circ} \mathrm{C}\right)$, and population growth is most rapid at temperatures greater than $80^{\circ} \mathrm{F}\left(26.7^{\circ} \mathrm{C}\right)$. The pupal stage is passed within a transparent, loose cocoon, usually attached to the underside of leaves. The moths emerge within 1-2 weeks after entering the pupal stage (Hayslip et al. 1953).

Diamondback moth is most abundant in southern Florida from December to February or March and can attack at any time during the crop cycle. By the end of May, moth counts in pheromone traps fall to near zero. Moth counts may rise in mid-fall through early winter, but activity is limited during that time. Populations build on winter weeds, such as wild mustard, before moving into winter and early spring cabbage plantings. From mid-winter through spring, diamondback moth is a serious pest, causing losses of up to $70 \%$ in the absence of control (Nuessly and Hentz 1999).

\section{CABBAGE LOOPER (TRICHOPLUSIA NI)}

Cabbage looper is also one of the most important annual pests for Florida cabbage growers. It is less of a problem in southern Florida, where it is considered a minor pest. In that part of the state, pheromone trap data show that adult populations are highest during the late spring and summer months, and in the late fall in some years (Nuessly and Hentz 1999). Cabbage looper does not enter diapause and cannot survive prolonged cold weather. The insect remains active and reproduces throughout the winter months only in the southern part of Florida (south of Orlando) (Capinera 2011b). In central Florida, cabbage looper populations peak during early fall and again during late spring (Leibee 1996). In general, cabbage looper is more of a problem on Florida cabbage during the fall than during the winter or spring.

Cabbage looper larvae damage plants by chewing holes in leaves. Smaller larvae remain on the lower leaf surface, while larger larvae produce larger holes throughout the leaf. In addition to feeding on the wrapper leaves, cabbage loopers may bore into the developing head. Some defoliation can be tolerated before head formation, but feeding damage and excrement left behind on heads make cabbage unmarketable. Cabbage with damage confined to wrapper leaves is marketable but with reduced value. Control has been shown to be justified in Texas when population densities reach 0.3 larvae per plant (Capinera 2011b). In Florida, an action threshold of 0.1 medium to large cabbage looper larvae per plant was developed for cabbage (Hayslip et al. 1953; Leibee 1996).

Eggs are deposited singly or in small clusters on either leaf surface, although more are found on the lower leaf surface. Each female moth can produce 300-600 eggs during the approximately 10-12 days it is alive. After the eggs hatch, additional larvae move to the lower leaf surface to feed. Two to four weeks after hatching, the mature larva forms a thin cocoon on the lower leaf surface, or in plant debris or soil. The pupal stage lasts approximately two weeks. Total time required for development from egg to adult can be as little as 18 days at $69.8^{\circ} \mathrm{F}\left(21^{\circ} \mathrm{C}\right)$ and 25 days at $89.6^{\circ} \mathrm{F}$ $\left(32^{\circ} \mathrm{C}\right)$ (Hayslip et al. 1953; Leibee 1996; Capinera 2011b).

\section{APHIDS}

Turnip aphid (Hyadaphis erysimi) and green peach aphid (Myzus persicae) are the most important aphids on Florida cabbage. Green peach aphid is a vector of turnip mosaic virus in Florida (Webb 2010).

Although cabbage aphid (Brevicoryne brassicae) may attack the crop at any stage, green peach aphid attacks cabbage mainly before heading begins. Aphids suck plant juices with their piercing-sucking mouthparts, resulting in yellowing and curling of leaves. Particularly when attacked as seedlings, plants may be stunted or die as a result of aphid feeding. Aphids can be protected from insecticide sprays within the curled leaves or inside the cupped leaves of headed plants (Hayslip et al. 1953).

\section{BEET ARMYWORM (SPODOPTERA EXIGUA)}

Beet armyworm is a sporadic pest on Florida cabbage, and it is usually kept under damaging levels by controls targeted to diamondback moth. Beet armyworm populations in southern Florida are highest from late March through mid-June, with a small rise in population from mid-August through October. Population rise in the late summer and fall is thought to be related to beet armyworm activity on late summer weeds, while the population increase in the spring coincides with the leafy vegetable production season in southern Florida (Nuessly and Hentz 1999).

The beet armyworm has a wide host range, and, besides cabbage, it also attacks vegetables such as asparagus, bean, beet, broccoli, cauliflower, celery, chickpea, corn, cowpea, eggplant, lettuce, onion, pea, pepper, potato, radish, 
spinach, sweet potato, tomato, and turnip, and field crops such as alfalfa, corn, cotton, peanut, safflower, sorghum, soybean, and tobacco. Many weeds also serve as hosts, including lambsquarters (Chenopodium album), pigweeds (Amaranthus spp.), purslane (Portulaca sp.), parthenium (Parthenium sp.), and mullein (Verbascum sp.). Larvae feed on both foliage and fruit of host plants. On cabbage, beet armyworm larvae consume greater amounts of leaf tissue than the diamondback moth but not as much as the cabbage looper. An action threshold of 0.3 beet armyworm larvae per plant has been used for cabbage in Texas. Since adults can readily invade a field from nearby crops or weeds, monitoring the crop twice a week for beet armyworm presence and damage is recommended (Capinera 2011a).

The insect is active the entire year in southern Florida, and it migrates annually into north Florida and rest of the southeastern United States (Nuessly and Hentz 1999). Females can lay up to 600 eggs each, usually in groups of about 100. Eggs are laid on the underside of lower leaves and are covered with fuzzy, white scales. Under warm conditions, eggs hatch within 2-3 days. The larvae feed from one to three weeks, in groups when younger and scattered on the plant when larger. Full-grown larvae pupate in the soil in a cocoon constructed from sand and bits of soil. Adults emerge within a week in warm temperatures (Sorenson and Baker 1983; Capinera 2011a).

\section{CABBAGE WEBWORM (HELLULA ROGATALIS)}

Like beet armyworm, cabbage webworm is seen sporadically and is controlled by treatments for diamondback moth. It is more of a problem in southern Florida. The pest can attack cabbage both in seedbeds and the field (Hayslip et al. 1953).

Cabbage webworm eggs are usually laid in plant buds. Upon hatching, the larvae feed on the underside of the leaves in the bud area, producing small holes. The larvae cover themselves with webs, which become covered with dirt and excrement. Larger larvae can burrow into buds, stems, and leaves. The insect may feed on the growing point, which prevents head formation, and the plant may appear lopsided. When fully grown, larvae pupate in the buds, on the sides of stems, or on the soil surface (Hayslip et al. 1953).

\section{IMPORTED CABBAGEWORM (ARTOGEIA RAPAE)}

Another minor pest, imported cabbageworm produces large holes in leaves and may attack the head near maturity, leaving damage similar to diamondback moth (Workman 1983). Imported cabbageworm feeding results in large, irregular holes in the leaves and the head's outer layers (Hayslip et al. 1953).

Female moths can lay several hundred eggs each within a cabbage field, attaching them to the underside of leaves. The egg stage lasts about one week, and the emerging caterpillars feed on the underside of the leaves. After about two weeks, the larvae attach themselves with silk to a support and pupate. The moths emerge in 1-2 weeks (Hayslip et al. 1953).

\section{CUTWORMS}

Cutworms affecting cabbage include black cutworm (Agrotis ipsilon) and granulate cutworm (Feltia subterranea).

Cutworms are stout, gray caterpillars with a greasy appearance. They are active at night, feeding on cabbage stems and leaves and other plants. During the day, they take refuge in the soil at the base of the plants. Recently transplanted cabbage is particularly susceptible to attack by cutworms, which can cut thin-stemmed plants off at or slightly below the soil surface. They also cut large holes in leaves touching the soil surface (Hayslip et al. 1953). Several plants in a row are usually affected, and when feeding, cutworms often pull the end of a leaf into a protected area of the soil (Workman 1983). Cutworms also eat into heading cabbage and may remain within the head during the day. Overall, while some damage to leaves and heads occurs, greatest losses from cutworm damage are the result of reduced stands (Hayslip et al. 1953).

Black cutworm is one of the most destructive cutworms and attacks a wide range of plants. Although cutworm larvae can migrate into a field from adjacent areas, most migration occurs by adults flying into the field. The moth deposits eggs in groups of 1-30 on leaves or stems near ground level. The egg stage lasts from 5 to 15 days, the larval stage lasts from three to four weeks, and the pupal stage takes 12 to 36 days. At high temperatures, when development is more rapid, the life cycle can be completed in six or seven weeks. Granulate cutworm's life cycle is similar to that of the black cutworm (Hayslip et al. 1953).

\section{MOLE CRICKETS (SCAPTERISCUS SPP. AND NEOCURTILLA HEXADACTYLA)}

Mole crickets are a problem in cabbage seedbeds, where they produce raised tunnels on the soil surface. Although they do not feed on the plant, their tunneling may cause cabbage seedlings to fall over (Workman 1983). Their enlarged front legs are adapted for burrowing, and they can 
also damage newly-transplanted cabbage plants by burrowing around them, resulting in drying of soil and roots. Mole crickets spend their entire life cycle in the soil and are nocturnal, becoming active at night and remaining in their tunnels during the day. Greatest damage occurs during warm, moist weather (Hayslip et al. 1953).

\section{SILVERLEAF WHITEFLY (BEMISIA ARGENTIFOLII)}

Silverleaf whitefly, previously known as strain B of the sweetpotato whitefly, is a common pest on cabbage in southern Florida. However, it does not severely damage the crop. Under heavy infestations, when the outer leaves become covered with whiteflies, the leaves are removed at harvest.

Adult females produce an average of 160 eggs each, depositing them on the lower surface of host plant leaves. The first nymphal (immature) stage, the crawler stage, attaches itself to the leaf near the empty egg case. The whitefly passes through three more sedentary nymphal stages, appearing like transparent scales, before molting to the adult stage. Whiteflies feed by sucking the plant's sap through their needle-like, piercing-sucking mouthparts. Like aphids, they extract large amounts of the plant's sap (phloem), excreting the excess liquid as honeydew, upon which sooty mold can grow (Johnson, Short, and Castner 2005; Norman et al. n.d.).

With a host range of more than 500 species of plants, the silverleaf whitefly has been observed to reproduce on at least 15 crops and 20 weed species in Florida. Whitefly populations commonly peak on the state's crops at the time of harvest, as the whitefly migrates from crop to crop throughout the year. In southern Florida, populations build on fall vegetables and move directly to overlapping spring crops. In west-central Florida, whitefly adults trapped in cabbage fields are highest from November until April or May. Cabbage can serve as a winter reservoir for whiteflies colonizing spring plantings of tomatoes and other vegetable crops in southwest Florida. Over the summer fallow period, whitefly populations are low because whiteflies are limited to weeds, such as water primrose, hairy indigo, and spurge. Weeds are poor hosts to the whitefly and usually harbor many natural enemies that reduce populations during that time (Schuster, Polston, and Price 1992; Stansly 1995; Norman et al. n.d.).

\section{Chemical Control}

In 2010, Florida growers applied insecticides totaling 7,400 pounds of active ingredient to $100 \%$ of the state's cabbage acreage. During the years when usage data was collected, $95 \%-100 \%$ of cabbage acreage has been treated with insecticides each year, with total annual usage ranging from 6,100 to 55,200 pounds of active ingredient. The most commonly used insecticides on Florida cabbage are Bacillus thuringiensis (B.t.) and spinosad. In fact, B.t. was the only insecticide with published use values for Florida cabbage in 2002. Older insecticidal materials used in Florida for cabbage were bifenthrin, carbaryl, chlorpyrifos, dimethoate, emamectin benzoate, endosulfan, esfenvalerate, imidacloprid, indoxacarb, lambda-cyhalothrin, malathion, methoxyfenozide, methomyl, permethrin, thiodicarb, tebufenozide, azadirachtin, azinphos-methyl, Beauveria bassiana, cypermethrin (beta or zeta), diazinon, disulfoton, fenpropathrin, insecticidal soaps, insecticidal oils, naled, oxydemeton-methyl, polyhedrosis viruses for corn earworm and beet armyworm, pymetrozine, pyrethrins, and sulfur.

Other insecticidal materials recently registered for use in Florida cabbage include thiamethoxam, esfenvalerate, acetamiprid, beta-cyfluthrin, clothianidin, flonicamid, pheromones, tebufenozide, chlorantraniliprole, buprofezin, gamma-cyhalothrin, potassium salts of fatty acids, pyriproxyfen, piperonyl butoxide, s-methoprene, spirotetramat, cyfuthrin, spiromesifen, sodium tetraborohydrate decahydrate, emamectin benzoate, spinetoram, novaluron, dinotefuran, kaolin, flubendiamide, cyromazine, flubendiamide, extract of Chenopodium ambrosioides, Paecilomyces sp., and Chromobacterium subtsugae (USDA/NASS 2010b; CDMS 2013).

\section{BACILLUS THURINGIENSIS}

The biopesticide Bacillus thuringiensis (B.t.) is the most important insect management tool for Florida cabbage growers. Cabbage growers use B.t. every year to manage diamondback moth and other lepidopteran larvae. A naturally occurring soil bacterium, B.t. produces spores and crystalline bodies that act as stomach poison to the insects that consume it. The most common formulations are highly specific for lepidopterous larvae (caterpillars) and do not harm beneficial organisms. However, it is most effective against smaller larvae. B.t. may be applied up to the day of harvest, meaning the pre-harvest interval (PHI) is 0 days, and the restricted-entry interval (REI) under the Worker Protection Standard is 4 hours.

\section{SPINOSAD}

Spinosad is a reduced risk broad-spectrum insecticide derived from fermentation of the naturally occurring soil bacterium Saccharopolyspora spinosa. Since its registration, 
spinosad has become one of the most important insecticides for Florida cabbage growers (Eger and Lindenberg 1998). It controls many lepidopterous larvae, dipteran leafminers, and thrips. It is used by Florida cabbage growers primarily to manage diamondback moth and cabbage looper but also to control imported cabbageworm and armyworm. Spinosad has low activity against most beneficial insects and is useful in integrated pest management (IPM) programs. Spinosad may be applied up to 1 day before harvest $(\mathrm{PHI}=1$ day), and the restricted entry interval (REI) under the Worker Protection Standard is 4 hours. For purposes of resistance management, a maximum of six diamondback moth treatments may be made per year (since this is a lower rate than the maximum of 0.16 $\mathrm{lb}$ ai/A). Additionally, no more than three consecutive treatments may be made in a 30 -day period, followed by a 30-day period free of spinosad. The maximum amount that can be used per crop is $0.45 \mathrm{lb}$ ai/A (CDMS 2013).

\section{Use of Insecticides in IPM Programs}

Action thresholds for caterpillar pests of cabbage were developed in Florida and Georgia during the 1970s and 1980s to reduce insecticide sprays on cabbage. Until then, growers had been spraying using a fixed schedule of once or twice weekly. Using insecticides based on early thresholds (the number of larvae present) was shown to greatly reduce insecticide sprays and still produce marketable cabbage. Thresholds were developed based on visual damage ratings and percent of plants with new damage, and these were as effective as the more time-consuming larvae counts. However, thresholds based on new damage tended to result in more insecticide applications. All thresholds were shown to be less effective when an atypical pest was present or a particular pest was present in very high numbers (Leibee et al. 1984; Leibee 1996).

An IPM program to manage diamondback moth in cabbage has been under development in Florida for several years. The program consists of multiple strategies, including using B.t. insecticides, biological control (parasitoid releases), trap crops, and pheromone treatments for mating disruption (Hu et al. 1998).

\section{Use of Insecticides in Resistance Management Programs}

Insecticide resistance in the control of cabbage insects in Florida has been a problem for more than 40 years. Diamondback moth is an agricultural pest that has demonstrated the ability to quickly become resistant to insecticides. From the 1940s through the 1970s, growers applied DDT, toxaphene, parathion, methoxychlor, mevinphos, endosulfan, naled, methomyl, and methamidophos to cabbage for control of multiple cabbage caterpillars. Cabbage looper resistance to DDT, parathion, and toxaphene was documented in 1957, and populations resistant to methomyl were found in the early 1980s. When the pyrethroids became available in the early 1980s, growers switched to permethrin and fenvalerate to control cabbage looper and diamondback moth, which became more difficult to control with the earlier insecticides. Permethrin and fenvalerate effectively controlled those pests until resistance began in the mid-1980s. Within a few years, growers were experiencing difficulty in controlling diamondback moth with those insecticides. In 1987, central Florida diamondback moth populations were found to be resistant to fenvalerate and methomyl but susceptible to chlorpyrifos, acephate, endosulfan, and thiodicarb. By the early 1990s, thiodicarb had also become less effective (Leibee and Savage 1992a; Leibee and Savage 1992b; Leibee and Capinera 1995; Leibee 1996).

Pyrethroids and carbamates became less effective during the late 1980s, forcing growers to modify their insecticide use. Growers switched to several organophosphates, endosulfan, and Bacillus thuringiensis kurstaki. None of these was completely effective, and resistance to B.t. kurstaki was confirmed in Florida in the early 1990s. Growers then switched to the newly introduced Bacillus thuringiensis aizawai-based insecticides, which offered greater diamondback moth control. In addition, reduced pyrethroids use resulted in greater natural control due to the return of parasites. Diamondback moth populations also appeared to develop greater susceptibility to B.t. kurstaki, which growers began using again. However, resistance has apparently been developing to B.t. aizawai (Leibee and Capinera 1995; Leibee 1996).

Resistance in diamondback moth populations in Florida has been largely attributed to the frequent use of single insecticides or classes of insecticides over time, as well as to the nearly continuous production of cabbage in isolated areas. During the 1980s, cabbage producers in Florida began to harvest later in the spring and transplant earlier in the summer, reducing the previous crucifer-free period that had existed between June and September. At the same time, container-grown transplants began to be produced during the summer months, giving diamondback moth continuous access to crucifers. The principal transplant producers have operated in the main field production areas, allowing easy movement of insect pests from fields to transplant houses at the end of the spring season and back to production fields at the start of the fall season. Both the development of insecticide resistance and the loss of natural enemies 
because of insecticide treatments for cabbage looper control contributed to the increase in diamondback moth populations in Florida during the 1980s. During this time, the diamondback moth became a major pest on cabbage. Intensive use of insecticides during the 1980s, combined with the increasing use of infested transplants and resulting greater insect pest problems, most likely contributed to the high degree of insecticide resistance found among cabbage pests in Florida (Leibee and Capinera 1995; Leibee 1996).

A number of recommendations were made to limit development of greater resistance problems in diamondback moth in Florida. Those included 1) avoiding cabbage production during the warmest months, when B.t.-based insecticides are least effective and insect problems are greatest; 2 ) destroying crop residues to avoid pest movement into new plantings; 3) using pest-free transplants; 4) inspecting the crop frequently, beginning at the seedling stage, and using action thresholds to minimize insecticide applications; 5) using pheromone traps to monitor adult activity and time insecticide applications; 6) using B.t. kurstaki and B.t. aizawai as the main insecticides to control diamondback moth, rotating the two to reduce resistance selection; and 7) avoiding the use of carbamates and eliminating the use of pyrethroids (Leibee and Capinera 1995).

\section{Cultural Control}

Mating disruption with sex pheromones was effective in reducing diamondback moth and cabbage looper populations in Florida cabbage. In field trials in northeast Florida, treating cabbage fields with sex pheromones controlled diamondback moth populations for most of the cabbage season, minimizing the need for pesticide sprays. In the trials, mating suppression was confirmed, but the effect of pheromone treatment on larval counts of cabbage looper was not evaluated because cabbage looper larvae were not present in sufficiently high numbers. Using pheromones is considered a promising management tactic if cabbage looper populations increase considerably (Mitchell et al. 1997a).

The use of trap crops has also been investigated to manage diamondback moth in Florida cabbage. A trap crop is a plant more attractive to the insect pest that lures it away from the more valuable crop. In preliminary studies, collard plants, when planted between rows of cabbage, were shown to have potential as a trap crop for diamondback moth. Collards also play an important role in maintaining populations of the natural enemy Diadegma insulare (Mitchell, $\mathrm{Hu}$, and Okine 1997). Recently in northeast Florida, planting collards around the perimeters of cabbage fields helped reduce pesticide sprays for diamondback moth on cabbage by $75 \%-100 \%$ over cabbage fields treated with conventional insecticides, producing equivalent quantity and quality of cabbage (Weaver 1999).

Another cultural control for cabbage looper moths is the use of row covers, which can prevent cabbage looper moths from laying their eggs on the plants. However, using row covers is not always economically feasible (Capinera 2011b). Cutworm damage can be reduced by plowing under weeds at least one month prior to planting (Hayslip et al. 1953).

\section{Biological Control}

Florida cabbage growers depend on the microbial insecticide Bacillus thuringiensis to manage diamondback moth and cabbage looper, among other caterpillar pests. Several other natural control agents help reduce pest population densities in cabbage. A nuclear polyhedrosis virus (NPV) naturally reduces cabbage looper populations in some years. Larvae consuming the virus inclusion bodies usually die within 5-7 days, after becoming blotchy, then creamy white and swollen, and eventually limp. The virus is spread from the disintegrated bodies of infected larvae, a process aided by rainfall. Cabbage looper mortality from NPV tends to be greater during years of greater rainfall. The Trichoplusia ni NPV can be effective, but it has a narrow host range and consequently has not been commercialized (Capinera 2011b). Another nuclear polyhedrosis virus highly specific to beet armyworm is considered to be the most important natural mortality factor for beet armyworm larvae (Capinera 2011a). A polyhedrosis virus is commercially available for corn earworm as well.

Other natural mortality agents of cabbage looper include tachinid parasitoids such as Voria ruralis, which attacks medium or large larvae, wasp parasitoids such as Trichogramma spp., which parasitize looper eggs, and predators such as the earwig Labidura riparia, which has been observed feeding on cabbage looper larvae and pupae in Florida crucifer fields. Bird predation of cabbage looper has also been observed in fields in Florida. Mass release of Trichogramma spp. has been studied in several crops and was effective in crucifers, but it has not been used by Florida cabbage growers (Leibee 1996; Capinera 2011b).

The parasitic wasp Cotesia plutellae was imported and released in Florida in 1990, and since then it has been released in Florida cabbage fields sporadically, but it has not established. Inundative releases of $C$. plutellae have also been evaluated for control of diamondback moth 
populations in cabbage fields in northeast Florida. While the release rates used in the latest study (about 3,082 per hectare over the season) were not considered to provide sufficient economic control of the pest, such releases in combination with other IPM tactics (trap crops, pheromones for mating disruption, and use of B.t. insecticides) may prove effective. Parasitism by C. plutellae was complementary to the natural parasitism occurring from the native Diadegma insulare (Leibee 1996; Mitchell et al. 1997b; Mitchell et al. 1999).

Diamondback moth populations in Florida also suffer a high parasitism rate by Trichogramma sp. and are affected by several pathogens, including Zoophthora spp. (Leibee 1996). Additional natural enemies of cabbage pests reported in Florida include the parasites Meteorus vulgaris, a braconid wasp that attacks granulate cutworm and fall armyworm in the Everglades area, the encyrtid wasp Copidosoma truncatellum, a parasite of the cabbage looper, the ichneumonid wasp Horogenes insularis, which attacks diamondback moth and cabbage looper, the braconid wasp Diatretus rapae, which parasitizes cabbage and turnip aphids, and the tachinid flies Archytas piliventris and Eucelatoria rubentis, which attack armyworms and cutworms.

Predators of cabbage insects reported in Florida include the pentatomid bugs Podisus maculiventris and Podisus mucronatus, which feed on cabbage loopers and imported cabbageworms, and the reduviid bug Zelus bilobus, which also attacks cabbage loopers and imported cabbageworms. Other predaceous bugs include the pentatomids Stiretrus anchorago and Euthyrhynchus floridanus, and the reduviids Arilus cristatus and Sinea diadema. In addition, ground beetles of the genus Calosoma have played a role in biological control of cabbage pests. The native species $C$. scrutator and C. sayi frequently feed on cutworms and armyworms. Finally, the ladybird beetles Cycloneda sanguinea immaculata, Hippodamia convergens, Ceratomegilla fuscilabris floridanus, Scymnus collaris, Scymnus terminatus, Exochomus marginipennis, Psyllobora sp., and Coccinella novemnotata are all aphid feeders found in Florida (Hayslip et al. 1953).

\section{Disease Management}

\section{Disease Pathogens}

Diseases are less of a problem than insect pests for Florida cabbage growers. Most of the diseases affecting cabbage are sporadic, but cabbage growers must contend with the presence of at least one major disease in most years. The most significant diseases on cabbage in Florida are black rot (caused by Xanthomonas campestris), sclerotinose (caused by Sclerotinia sclerotiorum), downy mildew (caused by Peronospora parasitica), and Alternaria leaf spot (caused by Alternaria spp.). Other diseases that occasionally affect cabbage in Florida include bacterial leaf spot (caused by Pseudomonas cichorii), damping-off (caused by Fusarium and Pythium spp.), turnip mosaic (caused by turnip mosaic virus), wirestem (caused by Rhizoctonia solani), and yellows (caused by Fusarium oxysporum f. conglutinans). White rust of foliage (caused by Albugo candida) and powdery mildew (caused by Erisyphe polygoni) are minor diseases on cabbage in Florida. Another condition characterized by tiny black specks on the foliage the week after harvest has an unknown origin. Additional minor problems include brown heart, caused by boron deficiency, and tipburn, caused by potassium deficiency (Momol, Raid, and Kucharek 2005).

\section{BLACK ROT (CAUSED BY XANTHOMONAS CAMPESTRIS PV CAMPESTRIS)}

Black rot is also called black spot or black leg. It is the most serious disease of cabbage in Florida and is most common when cabbage transplants are grown outdoors. It can occur at any time of the year, and it is difficult to control once it gets into a field. Losses of up to $10 \%$ are recorded annually. In addition to cabbage, black rot attacks other cole crops, including broccoli, cauliflower, kale, kohlrabi, Brussels sprouts, rutabaga, turnip, collards, radish, mustard, and water cress. It also attacks cruciferous weeds such as wild radish, pepper grass, and shepherds purse (Kucharek and Strandberg 2000a).

The bacteria that cause black rot enter cabbage through injuries or natural openings on the leaves. Mechanical injury during transplanting, particularly injury that results in wounds on the root system, is an ideal entry mechanism for the pathogen. Cracks in the tissue of older roots also offer an entry point, particularly when the soil is saturated with water. Injury from insect feeding is a minor source of entry. A more virulent strain of the bacteria, which is present in Florida, is more likely to enter plants through stomatal openings in the leaves (Kucharek and Strandberg 2000).

Symptoms may not appear on leaves until up to 43 days after infection. Early symptoms of black rot include stunting, yellowing leaves, and blackening veins. A yellow, wedge-shaped area may be produced at the ends of leaves. As the bacteria move down the leaf veins and into the plant's vascular system, the disease becomes systemic, as bacteria move within the vascular system to healthy leaves. 
Both leaf veins and vascular tissue become darkened, and leaves wilt and die. Plants are later dwarfed and produce one-sided heads (Kucharek and Strandberg 2000).

Plants at any growth stage can be infected by black rot. The disease is seed-borne, and plants from infected seeds die quickly after germination. When young seedlings are infected, the plants do not produce heads, and heads from plants infected later will deteriorate after harvest. In addition to being spread on seeds, the bacteria are spread by rain, irrigation, and any water movement in the field. The disease is most severe under warm and wet conditions. The bacteria can survive in undecomposed debris of crucifer plants, and it grows at temperatures ranging from $40^{\circ} \mathrm{F}$ to $97^{\circ} \mathrm{F}\left(4^{\circ} \mathrm{C}-36^{\circ} \mathrm{C}\right)$, although optimum temperature for its growth is between $80^{\circ} \mathrm{F}$ and $86^{\circ} \mathrm{F}\left(27^{\circ} \mathrm{C}-30^{\circ} \mathrm{C}\right)$. After plants are infected, symptom expression is greatest at temperatures between $68^{\circ} \mathrm{F}$ and $82^{\circ} \mathrm{F}\left(20^{\circ} \mathrm{C}-28^{\circ} \mathrm{C}\right.$ ) (Kucharek and Strandberg 2000).

\section{SCLEROTINOSE (CAUSED BY SCLEROTINIA SCLEROTIORUM)}

Sclerotinose, also called Sclerotinia watery rot or watery soft rot, is another important cabbage disease in Florida, but it does not occur each year. Its sporadic occurrence coincides with the simultaneous presence of cool and damp conditions. Optimum conditions for rapid disease development include temperatures of $60^{\circ} \mathrm{F}-70^{\circ} \mathrm{F}\left(15^{\circ} \mathrm{C}-21^{\circ} \mathrm{C}\right)$ and high humidity with dew formation (Pernezny and Purdy 2009).

The disease is first seen on leaves and stems close to the ground. Small, water-soaked spots appear and enlarge, accompanied by a growth of white mycelium (the body of the fungus). As the disease develops, the fungus grows upward on the plant, often spreading over the head and creating a soft, dark water-soaked mass on the leaves. Within this mass, many small, black sclerotia (resting structures) are produced. The sclerotia are characteristic of diseases caused by S. sclerotiorum, and these are the fungus' survival mechanism from season to season. Sclerotia may form on the surface of the head as the disease progresses and the fungus invades the whole plant. Plants with heavily infected stems will wilt, fall over, and eventually die. Sclerotinose often follows cold conditions or other types of plant injury (Momol, Raid, and Kucharek 2005).

Sclerotinia watery rot was a major disease in the Hastings area in the 1940s and 1950s, but declined in importance during the 1960s and 1970s. At that time, the disease was observed after hard freezes that damaged the cabbage plants at the soil line, where the fungus would enter the injured stem. Sclerotia were the source of inoculum for such infections. After falling to the ground and being incorporated into the soil during disking and bedding operations, the sclerotia produce fruiting bodies (apothecia) after at least 10 days of high soil moisture. The fruiting bodies produce spores that are carried by air currents to infect injured or dying cabbage tissue. From there, the infection can spread slowly by plant to plant contact. The fungus can also attack the plant from the soil without forming fruiting bodies and resulting spores. In that case, leaves in direct contact with the soil are infected, or infection occurs at the soil line. Infection resulting from spore dispersal can occur on all plant parts (Weingartner 1981).

\section{DOWNY MILDEW (CAUSED BY PERONOSPORA PARASITICA)}

Downy mildew occurs on cabbage in Florida in most years; however, losses are minimal (approximately 2\%) because growers effectively control the disease with chemical management. Fungicides are the principal means of downy mildew control by Florida cabbage growers, and the use of non-systemic fungicides is recommended. Strains of the fungus resistant to systemic fungicides develop more rapidly (Kucharek 2000a).

The fungus that causes downy mildew of cabbage also attacks other crucifers, such as cauliflower, collards, Chinese cabbage, Brussels sprouts, broccoli, kale, and kohlrabi (McRitchie 1973). The first symptoms of downy mildew are black specks and yellow-brown spots forming on the upper leaf surface, accompanied by a fluffy mold growth developing on the lower surface. Young leaves may fall off when infected, and on older leaves, the spots may coalesce, producing large, sunken, tan spots. The disease can attack young seedlings or plants that have already headed. On older cabbage plants, the disease produces dark, sunken spots, which may appear purplish, on the head or wrapper leaves. Downy mildew infection of older plants may leave them susceptible to sclerotinose-causing bacteria (Kucharek 2000a).

Disease development can be extremely rapid, affecting an entire field in 3-4 days under favorable conditions (cool, moist weather). Although spore production can occur at temperatures of $39^{\circ} \mathrm{F}-85^{\circ} \mathrm{F}\left(4^{\circ} \mathrm{C}-29^{\circ} \mathrm{C}\right)$, optimum temperatures are $53^{\circ} \mathrm{F}-61^{\circ} \mathrm{F}\left(12^{\circ} \mathrm{C}-16^{\circ} \mathrm{C}\right)$. Germination and penetration of the spores are most rapid at temperatures of $42^{\circ} \mathrm{F}-61^{\circ} \mathrm{F}\left(6^{\circ} \mathrm{C}-16^{\circ} \mathrm{C}\right)$ and can occur at any temperature from $39^{\circ} \mathrm{F}$ to $75^{\circ} \mathrm{F}\left(4^{\circ} \mathrm{C}-24^{\circ} \mathrm{C}\right)$. At temperatures around $75^{\circ} \mathrm{F}\left(24^{\circ} \mathrm{C}\right)$, symptoms occur in 3-4 days of infection. 
When temperatures are suitable, disease development progresses more rapidly under wetter conditions (Kucharek 2000a).

The fungus that causes downy mildew can be spread by infected transplants or windblown spores produced in the lesions on the lower leaf surface of infected plants. Another type of spore, functioning as a survival spore, is produced within infected plant tissue during crop senescence and may serve as a source of inoculum for later crops. However, the role of the survival spores in disease spread is considered minimal. The extent to which weeds serve as a source of inoculum is presently unclear (Kucharek 2000a).

\section{ALTERNARIA LEAF SPOT (CAUSED BY ALTERNARIA SPP.)}

Alternaria leaf spot can also be a major disease on Florida cabbage during the years it occurs. It tends to be more of a problem in northern Florida than in southern Florida. The fungus can be seedborne, being carried in the seed in the form of mycelium or on the outside of the seed in the form of spores. Alternaria spp. seedling infections are not common in Florida. However, when they occur, infected seeds can experience preemergent or postemergent seedling blight. If they don't kill the plant outright, stem lesions at the seedling stage will result in inferior produce size (Kucharek 2000b).

Leaf spots produced by Alternaria spp. are much more common in Florida. Initial symptoms of Alternaria leaf spot include small, dark spots on the leaves. A target spot can be seen as spots enlarge. Older spots enlarge to $2-3$ inches $(5-7.5 \mathrm{~cm})$ and may be black, brown, or tan. A yellow halo around brown lesions on the leaf edges can be used to distinguish Alternaria leaf blight from black rot. However, yellow halos are not always produced around leaf lesions. As disease development continues, leaves may yellow and die. Concentric bands or a solid mass of fuzzy dark green to black growth within leaf spots develops as a result of spore production. Spores are usually produced at night and released during the day. But during prolonged periods of overcast weather, spores may be produced continuously. Optimum temperatures for spore production are $75^{\circ} \mathrm{F}-82^{\circ} \mathrm{F}$ $\left(24^{\circ} \mathrm{C}-28^{\circ} \mathrm{C}\right)$, and new spores can be produced in $7-10$ days of infection under favorable temperature conditions for penetration and germination (Kucharek 2000b).

In addition to being produced on leaf spots, spores can be produced on crop debris. The fungus may survive on cruciferous weeds as well. Infections and lesion size increase substantially with longer periods of leaf wetting, as a result of prolonged dew periods or frequent rains (Kucharek 2000b).

\section{BACTERIAL LEAF SPOT (CAUSED BY PSEUDOMONAS CICHORII)}

Bacterial leaf spot is only occasionally a problem on cabbage in Florida. The disease produces small, slightly sunken spots that are gray to dark brown and that may appear as target spots (concentric rings). Bacterial leaf spot occurs principally on the wrapper leaves, but it may affect internal leaves when conditions are favorable. Overhead irrigation and poor field drainage favor disease development (Momol, Raid, and Kucharek 2005).

\section{DAMPING-OFF (CAUSED BY FUSARIUM AND PYTHIUM SPP.)}

Damping-off occurs in transplant seedbeds. Plants either fail to emerge, or in the case of postemergence damping-off, a water-soaked lesion develops on the stem at or just below the soil surface. The seedling later wilts, falls over, and then dies (Momol, Raid, and Kucharek 2005).

\section{TURNIP MOSAIC (CAUSED BY TURNIP MOSAIC VIRUS)}

Turnip mosaic, also called black ringspot, occasionally affects cabbage in Florida. The disease is transmitted by aphids, and it also affects other crucifers, beets, spinach, and tobacco, among others. Symptoms appear on infected plants when the temperature is $75^{\circ} \mathrm{F}-85^{\circ} \mathrm{F}\left(23.9^{\circ} \mathrm{C}-29.4^{\circ} \mathrm{C}\right)$. Leaves become mottled, and plants appear stunted. Mosaic symptoms develop first on the underside of leaves. As the tissue in the dark green spots dies, a ring spot pattern develops. Heads from plants that did not appear to be infected in the field may develop symptoms in postharvest storage (Momol, Raid, and Kucharek 2005).

\section{WIRESTEM (CAUSED BY RHIZOCTONIA SOLANI)}

Wirestem is an occasional problem for Florida cabbage growers. The causal fungus can attack roots, stems, and leaves. In some cases, a seedling's outer stem will shrivel, turn dark, and become tough. Under appropriate weather conditions, such seedlings can recover. However, if the fungus continues to grow up the stem, bottom rot and head rot may develop (Momol, Raid, and Kucharek 2005). 


\section{YELLOWS (CAUSED BY FUSARIUM OXYSPORUM F. CONGLUTINANS)}

Yellows is another occasional disease seen by Florida cabbage growers. The disease first occurs in the lower leaves, with the appearance of a yellow-green color. Yellowing of the tissue may move upward to the top leaves. Yellowed tissue turns brown, and premature shedding of the leaves occurs. Vascular tissue in the leaves and stems is blackened. Sometimes, only one side of the plant is infected, in which case the plant curls and bends (Momol, Raid, and Kucharek 2005).

\section{Chemical Control}

In 2010, Florida growers applied fungicides totaling 70,600 pounds of active ingredient to $99 \%$ of the state's cabbage acreage. The most commonly used fungicide on Florida cabbage was chlorothalonil with total usage of 65,600 pounds. Older fungicidal materials registered for use in Florida cabbage are copper compounds, azoxystrobin, Bacillus sp., fosetyl-Al, hydrogen dioxide, mefenoxam, PCNB, and sulfur (USDA/NASS 2010b; CDMS 2013). Other recently registered fungicidal materials are acibenzolar-s-methyl, metalaxyl, potassium phosphite, potassium bicarbonate, potassium phosphate, potassium silicate, pyraclostrobin, mancozeb, boscalid, penthiopyrad, dimethomorph, chloropicin, 1,3-dichloropropene, cyprodinil, fludioxonil, fluazinam, fluopicolide, triflumizole, cyazofamid, fenamidone, mandipropamid, metalaxyl, thiram, laminarin, Streptomyces lydicus, Glicoladium virens, Trichoderma sp., and oils (neem, clove, rosemary, and thyme) (CDMS 2013).

\section{CHLOROTHALONIL}

Chlorothalonil is a broad-spectrum chloronitrile fungicide used to manage Alternaria leaf spot and downy mildew (CDMS 2013). Chlorothalonil may be applied up to 7 days before harvest ( $\mathrm{PHI}=7$ days), and the restricted entry interval (REI) under the Worker Protection Standard is 12 hours. The minimum retreatment period is seven days, and the seasonal maximum application is $12 \mathrm{lb}$ ai/A.

In 2010, Florida growers applied an average of 0.9 pounds of active ingredient per acre at each application to $99 \%$ of cabbage acreage, an average of 6.7 times. Total usage was 65,500 pounds of active ingredient.

During the years usage data was collected, Florida cabbage growers applied chlorothalonil at an average rate of $0.80-1.42$ pounds of active ingredient per acre at each application to $39 \%-94 \%$ of cabbage acreage. Growers have made an average number of applications ranging from 4.6 to 5.7 each year, totaling $22,700-56,300$ pounds of active ingredient annually (USDA/NASS 2012).

\section{COPPER HYDROXIDE}

Florida cabbage growers use copper hydroxide to manage black rot, Alternaria leaf spot, and downy mildew. The restricted entry interval (REI) of copper hydroxide under the Worker Protection Standard is 24 hours (CDMS 2013).

\section{Cultural Control}

Black rot can be spread by infected seeds or during transplant production. Although resistant varieties are available, the most effective management is adequate sanitation while producing transplants. Cabbage growers can buy certified transplants as well as seeds that have been certified as being free of black rot. Regardless of the source of cabbage seeds, using the hot water treatment is an essential management tactic that effectively controls black rot; the hot water treatment is soaking the seeds at $122^{\circ} \mathrm{F}\left(50^{\circ} \mathrm{C}\right)$ for $30-35$ minutes.

Specific practices during transplant production include the use of clean flats and disease-free seed, destruction of diseased plants and residue after the harvest, avoiding the movement of contaminated soil, fumigation, or rotation of transplant beds, irrigation from a well and not from an open ditch, elimination of cruciferous weeds, raising transplant beds for adequate drainage, avoiding handling of plants while wet, and avoiding placing transplant beds within one-quarter mile of crucifer production fields. In addition, transplants should not be wetted down before transplanting, since black rot spreads most easily under moist conditions (Momol, Raid, and Kucharek 2005).

While the use of clean planting material is the key cultural control for black rot, most growers also stay out of the fields as much as possible during wet conditions to avoid spreading the disease. Additional cultural practices that should be followed together include planting in fields that have not been in crucifer production for 12 months, plowing down crucifer fields just after harvest, and thoroughly cleaning all equipment and tools prior to use in the field or transplant bed (Kucharek and Strandberg 2000; Momol, Raid, and Kucharek 2005).

The best cultural control for sclerotinose, as well as most other diseases, is wider plant and row spacing, which cut down on long dew periods. However, to maximize yield, most growers do not increase spacing as a disease management practice. Additional recommendations for cultural control of sclerotinose include rotating with a crop that is 
not susceptible to Sclerotinia (e.g., sweet corn), turning the soil at least six inches when plowing, avoiding the use of overhead irrigation, and completely flooding or intermittently flooding for six weeks during the summer, if possible (Momol, Raid, and Kucharek 2005).

Destruction or burial of old plant beds and residues in harvested fields aids in managing Alternaria leaf spot and downy mildew. Elimination of cruciferous crops and weeds around seedbeds, rotation with non-cruciferous crops, and the use of disease-free seeds and transplants also aid in managing those diseases. Turnip mosaic can be managed by eliminating the weed hosts of the virus, particularly mustard-type weeds, both in the seedbed and field. Early control of aphids, especially in seedbeds, is the other key to reducing virus incidence. Cultural controls for wirestem include rotating crops on both seedbeds and fields, providing adequate drainage, cultivating as soon as possible after heavy rains to aerate and dry the soil, and avoiding planting in crop debris or a green manure crop that has recently been incorporated. For yellows, disease-free transplants should be used, and the only available control once soil has been infested is using resistant varieties (Kucharek 2000b; Momol, Raid, and Kucharek 2005).

\section{Postharvest Decays and Their Management}

Excessive trimming of wrapper leaves may cause the more susceptible inner leaves to wilt. In addition to contributing to wilting, cuts or breaks can provide an entry site for disease pathogens. The postharvest decays watery soft rot, bacterial soft rot, gray mold rot, Alternaria leaf spot, and black leaf speck can all affect cabbage during the postharvest period (Sargent et al. 2007).

\section{Nematode Management}

\section{Nematode Pests}

Plant-parasitic nematodes are microscopic roundworms found in soils. They primarily attack plant roots. General symptoms of nematode damage include stunting, premature wilting, leaf yellowing, and related symptoms characteristic of nutrient deficiencies. Stunting and poor stand developments occur in patches throughout the field as a result of the irregular distribution of nematodes within the soil. Root-knot, sting, stubby root, and awl nematodes are all important pests of crucifers, and cyst nematode is a serious pest in central Florida (Noling 2009; Noling 2012).

\section{ROOT-KNOT NEMATODES (MELOIDOGYNE SPP.)}

Many cruciferous plants are hosts to common species of root-knot nematodes. In greenhouse tests, moderate levels of root galling and egg masses occurred on cabbage plants infested with three species of root-knot nematodes (M. javanica, M. incognita races 1 and 3, and M. arenaria) (McSorley and Fredrick 1995).

Root-knot nematodes enter the host plant root as second stage juveniles and settle within the root to establish a feeding site. At the feeding site, nematode secretions cause the surrounding plant cells to enlarge and multiply, producing the characteristic galls associated with root-knot attack. As more nematodes enter the root and feeding continues, the galls fuse to form large tumors on the roots. Within the root, the developing female molts several times before developing into a swollen, pear-shaped adult. The adult may live in the host plant for several months, laying hundreds to several thousand eggs that are released into the soil. Low temperatures or very dry soil conditions can cause eggs to hatch more slowly. Root deformation and injury caused by root-knot nematodes reduce root area and interfere with water and nutrient uptake. Resulting symptoms include stunting, wilting, chlorosis, and yield loss. In addition to expending the plant's resources, the gall tissue is more susceptible to secondary infections such as root rots (Stokes 1972; Crow and Dunn 2005; Noling 2012).

\section{STING NEMATODES (BELONALAIMUS LONGICAUDATUS)}

Cabbage in Florida often experiences severe yield losses because of sting nematodes (White and Rhoades 1992). Sting nematodes are ectoparasites, remaining outside the plant root and feeding superficially at or near the root tip. Affected root tips turn yellow and later necrotic, with cavities forming and the root tip swelling slightly. Damage from sting nematode feeding inhibits root elongation and causes roots to form tight mats and appear swollen, resulting in a "stubby root" or "coarse root" appearance (Christie 1959; Crow and Dunn 2005; Esser 1976; Noling 2012).

Sting nematodes are especially damaging to seedlings and transplants. Death of transplants on highly infested sites can leave gaps of missing plants or patches of plants lacking vigor. In northern Florida, sting nematodes are most abundant in April and May. Sting nematodes prefer sandy soils (with $84 \%-94 \%$ sand) and are most abundant in the 
upper 12 inches $(30 \mathrm{~cm})$. Optimum soil temperature for this nematode is $77^{\circ} \mathrm{F}-90^{\circ} \mathrm{F}\left(25^{\circ} \mathrm{C}-32^{\circ} \mathrm{C}\right)$, and optimum soil moisture is about 7\% (Christie 1959; Crow and Dunn 2005; Esser 1976; Noling 2012).

\section{STUBBY-ROOT NEMATODES (TRICHODORUS SPP., PARATRICHODORUS SPP.)}

Stubby-root nematodes feed externally on the root surface and remain in the soil throughout their life cycle. They mainly feed at the tip of the growing root, stopping root elongation. The result can be a short, stubby root system with swollen root branches. Their feeding may also cause abnormal growth of lateral roots and increased production of branch roots. In Florida, stubby-root nematodes are found mainly in sandy or sandy loam soils, but also occur in muck soils. In addition to cabbage, the principal crops injured by this nematode in Florida include beets, corn, celery, cauliflower, chayote, and several grasses. Stubby-root nematode populations build up quickly in the presence of a suitable host and likewise decrease quickly when a host is no longer available (Christie 1959; Crow and Dunn 2005; MacGowan 1983).

\section{AWL NEMATODES (DOLICHODORUS SPP.)}

Awl nematodes also feed superficially from the outside of the plant root, inhibiting root elongation. Awl nematodes are similar to sting nematodes in appearance, habits, and the plant injury symptoms as a result of their feeding (Christie 1959; Crow and Dunn 2005).

\section{Chemical Control}

Ethoprop, fenamiphos, metam, and 1,3-dichloropropene are the nematicides registered for use on cabbage in Florida. Methyl bromide has been phased out with no critical use exemption for use in cabbage (CDMS 2013).

\section{Cultural Control}

The use of pest-free transplants is the most important cultural control for nematodes on cabbage. Transplants should be produced in a sterile growing medium or fumigated soil (Noling 2009).

Some resistance to sting nematodes has been found in several cabbage varieties tested in Florida. However, using nematode resistance alone has not been found to be economically feasible (White and Rhoades 1992).

\section{Weed Management}

\section{Weed Pests}

Weeds can reduce cabbage yields by competing for nutrients, water, and light. Managing weeds early in the season is particularly important to maintain crop vigor and yield. Since cabbage is largely a winter crop, many weed species are winter annuals. Wild radish is a major weed in Florida cabbage fields. Cutleaf evening primrose and Carolina geranium may also be present. In the early spring or late fall, there may be problems with summer annuals like amaranth, lambsquarters, and Pennsylvania smartweed, among others (Dittmar and Stall 2010).

\section{WILD RADISH (RAPHANUS RAPHANISTRUM)}

Wild radish is a winter annual that dies when hot weather begins, although some plants can live for a whole year in Florida. It can reach 1 meter (3.28 feet) in height. The stems have prickly hairs when the plant is younger and become smooth as the plant matures. The plant has one to several branches, and the leaves are hairy, with deep, rounded lobes. Wild radish germinates rapidly. The plant is often confused with wild mustard (Brassica kaber), but wild mustard is not found as a weed in Florida crops (Hall, Vandiver, and Ferrell 2012a).

Wild radish can have different effects on cabbage yield depending on when it occurs in the season. For example, during the warmer part of the spring and fall, the presence of up to 16 wild radish plants per meter (3.28 feet) of cabbage row will not reduce cabbage yields. However, during the cooler part of the season, only one wild radish plant per meter will significantly reduce cabbage yields (Dittmar and Stall 2010). In general, wild radish is a poor competitor with cabbage during the spring planting season (Steed et al. 1998).

\section{CUTLEAF EVENING PRIMROSE (OENOTHERA LACINIATA)}

Cutleaf evening primrose is an annual plant with hairy stems that branch at the base. Its long, narrow leaves are deeply cut near the base (Miller et al. 1975).

\section{CAROLINA GERANIUM (GERANIUM CAROLINIANUM)}

Carolina geranium is a winter annual with smooth, reddish stems that branch widely at the base (Miller et al. 1975). Its many branches form a circular growth from the plant's center, and it may rise to $0.6 \mathrm{~m}$ ( 2 feet) tall from a tap root (Hall, Vandiver, and Ferrell 2012b). 


\section{AMARANTH (AMARANTHUS SPP.)}

Amaranths (pigweeds) are summer annual broadleaf weeds with erect stems that grow to 2 meters (6.5 feet) tall. Several species of amaranth are present in Florida; the most important are smooth pigweed (Amaranthus hybridus), spiny amaranth (A. spinosus), and livid amaranth (A. lividus). Amaranths or pigweeds reproduce solely by seed, producing very small, dark seeds. Smooth pigweeds flower from July to November, and spiny amaranth flowers from June to October. They prefer open areas with bright sunlight (Lorenzi and Jeffery 1987).

\section{LAMBSQUARTERS (CHENOPODIUM ALBUM)}

Lambsquarters is an erect, summer annual that grows to 2 meters (6.5 feet) tall. It grows well on all soil types and over a range of soil $\mathrm{pH}$ values (Hall, Vandiver, and Ferrell 2012c).

\section{PENNSYLVANIA SMARTWEED (POLYGONUM PENNSYLVANICUM)}

Pennsylvania smartweed is a summer annual with smooth, branching stems and smooth, pointed leaves. It grows from 1 to 4 feet (0.3-1.2 meters) tall (Miller et al. 1975).

\section{Chemical Control}

In 2006, Florida growers applied herbicides totaling 4,100 pounds of active ingredient to $52 \%$ of the state's cabbage acreage. During the years when usage data was collected, $52 \%-89 \%$ of Florida's cabbage acreage was treated with herbicides each year, with total annual usage ranging from 4,100 to 13,000 pounds of active ingredient (USDA/ NASS 2010b). Historically, the most commonly reported herbicides used on cabbage in Florida are trifluralin, metolachlor, and napropamide, but DCPA, glyphosate, oxyfluorfen, sethoxydim, paraquat, bensulide, pelargonic acid, and clethodim are also available for use on cabbage (USDA/ NASS 2012). Other active ingredients recently registered for weed management in cabbage include carfentrazone-ethyl, clomazone, pyraflufen-ethyl, oxyfluorfen, d-limonene, sethoxydim, pendimethalin, clopyralid, ammoniated soap of fatty acids and oils (cinnamon and clove) (CDMS 2013).

\section{Cultural Control}

Cultural weed management practices include crop rotation, cover cropping, high-density planting, mulching, cultivation, and flooding. Cabbage growers in northern Florida tend to cultivate more than those in southern Florida, who use herbicides to a greater extent (Dittmar and Stall 2010).

\section{References and Additional Information}

Capinera, J.L. 2011a. Beet Armyworm, Spodoptera exigua (Hübner) (Insecta: Lepidoptera: Noctuidae). EENY-105. Gainesville: University of Florida Institute of Food and Agricultural Sciences. http://edis.ifas.ufl.edu/in262.

Capinera, J.L. 2011b. Cabbage Looper, Trichoplusia ni (Hübner) (Insecta: Lepidoptera: Noctuidae). EENY-116. Gainesville: University of Florida Institute of Food and Agricultural Sciences. http://edis.ifas.ufl.edu/in273.

CDMS (Crop Data Management Systems, Inc.). 2013. CDMS Label Search. http://premier.cdms.net/webapls/

Christie, J.R. 1959. Plant Nematodes, Their Bionomics and Control. Gainesville: University of Florida, Florida Agricultural Experiment Station.

Crow, W.T., and R.A. Dunn. 2012. Introduction to Plant Nematology. ENY-016. Gainesville: University of Florida Institute of Food and Agricultural Sciences. http://edis.ifas. ufl.edu/ng006.

Dittmar, P.J., and W.M. Stall. 2012. Weed Control in Cole or Brassica Leafy Vegetables (Broccoli, Cabbage, Cauliflower, Collards, Mustard, Turnips, Kale). HS-189. Gainesville: University of Florida Institute of Food and Agricultural Sciences. http://edis.ifas.ufl.edu/wg028.

Eckel, C.S., D.M. Dunbar, S.M. White, and J.A. Norton. 1996. "Experience with Emamectin Benzoate for Control of Lepidoptera Pest Species in Florida Vegetable Production.” Proc. Fla. State Hort. Soc. 109:205-207.

Eger, J.E., and L.B. Lindenberg. 1998. "Utility of Spinosad for Insect Control in Florida Vegetables." Proc. Fla. State Hort. Soc. 111:55-57.

Esser, R.P. 1976. Sting Nematodes, Devastating Parasites of Florida Crops. Nematology Circular No. 18. Gainesville: Florida Department of Agriculture and Consumer Services, Division of Plant Industry.

Florida Department of Agriculture and Consumer Services (FDACS). 2012. Florida Agricultural by the Numbers. Tallahassee: FDACS. http://www.florida-agriculture.com/ brochures/P-01304.pdf.

Hall, D.W., V.V. Vandiver, and J.A. Ferrell. 2012a. Wild Radish, Raphanus raphanistrum L. SP-37. Gainesville: 
University of Florida Institute of Food and Agricultural Sciences. http://edis.ifas.ufl.edu/fw032.

Hall, D.W., V.V. Vandiver, and J.A. Ferrell. 2012b. Carolina Geranium, Geranium carolinianum L. SP-37. Gainesville: University of Florida Institute of Food and Agricultural Sciences. http://edis.ifas.ufl.edu/fw017.

Hall, D.W., V.V. Vandiver, and J.A. Ferrell. 2012c. Lamb'squarters (Common Lamb's-quarters), Chenopodium album L. SP-37. Gainesville: University of Florida Institute of Food and Agricultural Sciences. http://edis.ifas.ufl.edu/fw011.

Hayslip, N.C., W.G. Genung, E.G. Kelsheimer, and J.W. Wilson. 1953. Insects Attacking Cabbage and Other Crucifers in Florida. Gainesville: University of Florida, Florida Agricultural Experiment Station.

Hu, G.Y., E.R. Mitchell, D.H. Sieglaff, and J.S. Okine. 1998. "Field Production of Two Species of Parasitoids of the Diamondback Moth (Lepidoptera: Plutellidae)." Florida Entomologist 81(4):526-534. http://www.fcla.edu/FlaEnt/ fe81p526.pdf.

International Agricultural Trade and Policy Center. 2009. Interactive Budgets 2008-2009. Gainesville: University of Florida Institute of Food and Agricultural Sciences. http:// www.fred.ifas.ufl.edu/iatpc/ibudgets09.php.

Jansson, R.K., R.F. Peterson, P.K. Mookerjee, W.R. Halliday, J.A. Argentine, and R.A. Dybas. 1997. "Development of a Novel Soluble Granule Formulation of Emamectin Benzoate for Control of Lepidopterous Pests." Florida Entomologist 80(4):425-443. http://www.fcla.edu/FlaEnt/ fe80p425.pdf.

Johnson, F.A., D.E. Short, and J.L. Castner. 2005. Sweetpotato/Silverleaf Whitefly Life Stages and Damage. SP-90. Gainesville: University of Florida Institute of Food and Agricultural Sciences.

Kucharek, T., and Strandberg, J. 2000. Black Rot of Crucifers. PP-13. Gainesville: University of Florida Institute of Food and Agricultural Sciences. https://edis.ifas.ufl.edu/ vh013.

Kucharek, T. 2000a. Downy Mildew of Crucifers. Plant Pathology Department Fact Sheet PP-33. Gainesville: University of Florida Institute of Food and Agricultural Sciences.
Kucharek, T. 2000b. Alternaria Diseases of Crucifers. Plant Pathology Fact Sheet PP-34. Gainesville: University of Florida Institute of Food and Agricultural Sciences.

Leibee, G.L. 1996. "Insect Pest Management in Crucifers in Florida." In Pest Management in the Subtropics: Integrated Pest Management - A Florida Perspective, edited by D.

Rosen, F. D. Bennett, and J. L. Capinera, 413-422. Andover, UK: Intercept.

Leibee, G.L. 2004. Professor of Entomology, University of Florida, Mid-Florida Research and Education Center, Apopka, FL. Personal Communication, May 5, 2004.

Leibee, G.L., R.B. Chalfant, D.J. Schuster, and R.B. Workman. 1984. "Evaluation of Visual Damage Thresholds for Management of Cabbage Caterpillars in Florida and Georgia." J. Econ. Entomol. 77(4):1008-1011.

Leibee, G.L., and J.L. Capinera. 1995. "Pesticide Resistance in Florida Limits Management Options." Florida Entomologist 78(3):386-399. http://www.fcla.edu/FlaEnt/fe78p386. pdf.

Leibee, G.L., and K.E. Savage. 1992a. "Evaluation of Several Insecticides for Control of Diamondback Moth and Cabbage Looper in Cabbage in Central Florida with Observations on Insecticide Resistance in the Diamondback Moth." Florida Entomologist 75(4):585-591. http://journals.fcla. edu/flaent/article/view/58893.

Leibee, G.L., and K.E. Savage. 1992b. “Toxicity of Selected Insecticides to Two Laboratory Strains of InsecticideResistant Diamondback Moth (Lepidoptera: Plutellidae) from Central Florida." J. Econ. Entomol. 85(6):2073-2076.

Lorenzi, H.J., and L.S. Jeffery. 1987. Weeds of the United States and Their Control. New York: Van Nostrand Reinhold Company.

MacGowan, J.B. 1983. The Stubby-Root Nematode, Paratrichodorus christiei (Allen 1957) Siddiqi 1974. Nematology Circular No. 97. Gainesville: Florida Department of Agriculture and Consumer Services, Division of Plant Industry.

McRitchie, J.J. 1973. Downy Mildew of Cabbage. Plant Pathology Circular No. 127. Gainesville: Florida Department of Agriculture and Consumer Services, Division of Plant Industry. 
McSorley, R., and J.J. Frederick. 1995. "Responses of Some Common Cruciferae to Root-Knot Nematodes." Supplement to the Journal of Nematology 27(4S):550-554.

Miller, J.F., A.D. Worsham, L.L. McCormick, D.E. Davis, R. Cofer, and J.A. Smith. 1975. Weeds of the Southern United States. Gainesville: University of Florida Institute of Food and Agricultural Sciences.

Mitchell, E.R., G.Y. Hu, and J.S. Okine. 1997. “Diamondback Moth (Lepidoptera: Plutellidae) Infestation and Parasitism by Diadegma insulare (Hymenoptera: Ichneumonidae) in Collards and Adjacent Cabbage Fields." Florida Entomologist 80(1):54-62. http://www.fcla.edu/FlaEnt/ fe80p54.pdf.

Mitchell, E.R., G.Y. Hu, J.S. Okine, and J.R. McLaughlin. 1997a. "Mating Disruption of Diamondback Moth (Lepidoptera: Plutellidae) and Cabbage Looper (Lepidoptera: Noctuidae) in Cabbage Using a Blend of Pheromones Emitted from the Same Dispenser." J. Entomol. Sci. 32(2):120-137.

Mitchell, E.R., F.C. Tingle, R.C. Navasero-Ward, and M. Kehat. 1997b. "Diamondback Moth (Lepidoptera: Plutellidae): Parasitism by Cotesia plutellae (Hymenoptera: Braconidae) in Cabbage." Florida Entomologist 80(4):477-489. http:// www.fcla.edu/FlaEnt/fe80p477.pdf.

Mitchell, E.R., G.Y. Hu, J.S. Okine, and J.E. Carpenter. 1999. "Parasitism of Diamondback Moth (Lepidoptera: Plutellidae) Larvae by Cotesia plutellae (Hymenoptera: Braconidae) and Diadegma insulare (Hymenoptera: Ichneumonidae) in Cabbage Fields after Inundative Releases of C. plutellae." J. Entomol. Sci. 34(1):101-112.

Momol, T., R. Raid, and T. Kucharek. 2005. 2006 Florida Plant Disease Management Guide: Crucifers. Plant Pathology Department PDMG-V3-37. Gainesville: University of Florida Institute of Food and Agricultural Sciences.

Noling, J.W. 2009. Nematode Management in Crucifers (Broccoli, Brussels Sprouts, Cabbage, Cauliflower, Chinese Cabbages, Collards, Mustards, Radishes, Rutabagas, and Turnips). EENY-024. Gainesville: University of Florida Institute of Food and Agricultural Sciences. http://edis.ifas. ufl.edu/ng024.

Noling, J.W. 2012. Nematodes and Their Management. ENY625. Gainesville: University of Florida Institute of Food and Agricultural Sciences. http://edis.ifas.ufl.edu/cv112.
Norman, J.W., Jr., D.G. Riley, P.A. Stansly, P.C. Ellsworth, and N.C. Toscano. n.d. Management of Silverleaf Whitefly: A Comprehensive Manual on the Biology, Economic Impact and Control Tactics. Washington, DC: USDA/CSREES.

Nuessly, G., and M. Hentz. 1999. EREC Moth Pheromone Trap Data. Belle Glade: University of Florida Everglades Research and Education Center.

Olson, S.M., P.J. Dittmar, G.E. Vallad, S.E. Webb, and S.A. Smith. 2012. Cole Crop Production in Florida. HS724. Gainesville: University of Florida Institute of Food and Agricultural Sciences. http://edis.ifas.ufl.edu/cv122.

Pernezny, K., and L.H. Purdy. 2009. Sclerotinia Diseases of Vegetable and Field Crops in Florida. PP-22. Gainesville: University of Florida Institute of Food and Agricultural Sciences. http://edis.ifas.ufl.edu/vh015.

Sargent, S.A., M.A. Ritenour, J.K. Brecht, and J.A. Bartz. 2007. Handling, Cooling and Sanitation Techniques for Maintaining Postharvest Quality. HS719. Gainesville: University of Florida Institute of Food and Agricultural Sciences.

Schuster, D.J., J.E. Polston, and J.F. Price. 1992. "Reservoirs of the Sweetpotato Whitefly for Tomatoes in West-Central Florida." Proc. Fla. State Hort. Soc. 105:311-314.

Sorenson, K.A., and J.R. Baker. 1983. Insects and Related Pests of Vegetables, Some Important, Common and Potential Pests in the Southeastern United States. Raleigh, NC: North Carolina State University, North Carolina Agricultural Extension Service.

Stall, W. 2004. Professor of Horticultural Sciences, University of Florida, Gainesville, FL. Personal Communication, May 5, 2004.

Stansly, P.A. 1995. "Seasonal Abundance of Silverleaf Whitefly in Southwest Florida Vegetable Fields." Proc. Fla. State Hort. Soc. 108:234-242.

Steed, S.T., W.M. Stall, J.A. Dusky, and D.G. Shilling. 1998. "Interference of Wild Radish (Raphanus raphanistrum L.) on Cabbage Production." 1998 Proceedings, Southern Weed Science Society.

Stokes, D.E. 1972. Root-Knot Nematodes (Meloidogyne spp.). Nematology Circular No. 11. Gainesville: Florida Department of Agriculture and Consumer Services, Division of Plant Industry. 
United States Department of Agriculture/National Agricultural Statistics Service (USDA/NASS). 2009. 2007 Census of Agriculture, Florida State and County Data. http:// www.agcensus.usda.gov/Publications/2007/Full_Report/ Volume_1,_Chapter_1_State_Level/Florida/flv1.pdf.

USDA/NASS. 2010a. Agriculture Chemical Usage Survey Guide. http://www.nass.usda.gov/Surveys/ Guide_to_NASS_Surveys/Chemical_Use/.

USDA/NASS. 2010b. Quick Statistics. http://www.nass.usda. gov/Statistics_by_State/Florida/index.asp.

USDA/NASS. 2011. Agricultural Statistics Annual, U.S. Dept. of Agriculture/National Agricultural Statistics Service. http://www.nass.usda.gov/Publications/Ag_Statistics/2011/ index.asp.

USDA/NASS. 2012. Agricultural Statistics Annual, U.S. Dept. of Agriculture/National Agricultural Statistics Service. http://www.nass.usda.gov/Publications/Ag_Statistics/.

Weaver, T. 1999. "Trap Crops Prove Irresistible to Diamondbacks." Agricultural Research Magazine 47(3):26. http://www.ars.usda.gov/is/AR/archive/mar99/diam0399. htm.
Webb, S.E. 2010. Insect Management for Crucifers (Cole Crops) (Broccoli, Cabbage, Cauliflower, Collards, Kale, Mustard, Radishes, Turnips). ENY-464. Gainesville: University of Florida Institute of Food and Agricultural Sciences. http://edis.ifas.ufl.edu/ig150.

Weingartner, D.P. 1981. Sclerotinia Watery Rot of Crucifers in NE Florida. Hastings Research Report PR1981-8. Hastings: University of Florida Agricultural Research Center.

White, J.M., and H.L. Rhoades. 1992. "Screening Cabbage Varieties for Nematode Resistance." Proc. Fla. State Hort. Soc. 105:321-323.

Workman, R.B. 1983. "Diagnosis of Insect or Similar Damage on Crops in the Hastings Area." Hastings ARC Research Report 1983-1. Hastings: University of Florida Agricultural Research Center. 